\title{
Forage-SAFE: a model for assessing the impact of tree cover on wood pasture profitability
}

\author{
GARCÍA DE JALÓN $\mathrm{S}^{1 *}$, GRAVES A ${ }^{1}$, MORENO $\mathrm{G}^{2}$, PALMA JHN ${ }^{3}$, CROUS-DURÁN J ${ }^{3}, \mathrm{KAY} \mathrm{S}^{4}$, BURGESS PJ $^{1}$
}

1. Cranfield University, Cranfield, Bedfordshire, MK43 OAL, UK

2. Forestry Research Group, INDEHESA, Universidad de Extremadura, 10600, Plasencia, Spain

3. Forest Research Centre, University of Lisbon, Tapada da Ajuda, 1349-017 Lisboa, Portugal

4. Agroscope. Research Division Agroecology and Environment. Reckenholzstrasse 191, CH8046 Zürich, Switzerland

Contact e-mails: p.burgess@cranfield.ac.uk and silvestre.garciadejalon@bc3research.org.

\begin{abstract}
Whilst numerous studies have examined the environmental benefits of introducing additional trees within wood pasture systems few studies have assessed the impact on farm profitability. This paper describes a model, called Forage-SAFE, which has been developed to improve understanding of the management and economics of wood pastures. The model simulates the daily balance between food production and the livestock demand for food to estimate annual farm net margins. Parameters in Forage-SAFE such as tree cover density, carrying capacity, and type of livestock can be modified to analyse their interactions on profitability and to identify optimal managerial decisions against a range of criteria. A modelled dehesa wood pasture in South-western Spain was used as a case study to demonstrate the applicability of the model. The results for the modelled dehesa showed that for a carrying capacity of 0.44 livestock units per hectare the maximum net margin was achieved at a tree cover of around $53 \%$ with a mixture of Iberian pigs ( $28 \%$ of the livestock units) and ruminants (72\%). The results also showed that the higher the carrying capacity the more profitable the tree cover was. This was accentuated as the proportion of Iberian pigs increased.
\end{abstract}

Keywords: Wood pasture, Agroforestry, Tree cover, Dehesa, Model, Profitability

\section{Introduction}

Wood pastures are silvopastoral agroforestry systems with irreplaceable ecological, social, and cultural values. Wood pastures occupy around 20.3 million ha in the $27 \mathrm{EU}$ member states which represents around $4.7 \%$ of the European land (Plieninger et al., 2015); the area of grazed wood pasture in the EU has been estimated to be 15.1 million ha (den Herder et al., 2017). During the twentieth century, the area of wood pastures in Europe has declined either through agricultural intensification or abandonment. However, an increasing appreciation of the socio-economic and biodiversity value of wood pastures has led to conservation organisations, national governments, and the EU promoting wood pasture conservation across Europe (Bergmeier et al., 2010). 
Wood pastures are complex systems where trees and shrubs, grass fodder and livestock interact in ways that vary with location and time. This makes it difficult to determine the impact of specific farm-management decisions on farm profitability. For instance whilst studies like Moreno and Pulido (2009) and López-Díaz et al. (2015) indicate that increased tree cover has the potential to improve pasture production and profitability, it is difficult to determine the tree effect in monetary terms or to identify the tree cover density which maximises profitability. In addition, previous modelling analyses of agroforestry economics have often been undertaken at an annual time-step (e.g. Graves et al., 2011; García de Jalón et al., 2018) which is not suited to evaluation of the moderating effects of trees on seasonal pasture production. This paper therefore presents a bio-economic model, called Forage-SAFE, which has been developed to evaluate the management and economics of wood pastures. A key feature of the model is that it can simulate the daily balance between food production and the livestock demand for food in wood pasture systems. The objective in developing the model was to gain a better understanding of the effect of farm-management decisions regarding tree, pasture and livestock on farm profitability.

A bio-economic model of wood pastures requires algorithms that explain the interactions between trees and pasture production. Numerous studies have measured the effect of trees on pasture production (Pardini et al., 2010; Moreno et al., 2007; Gea-Izquierdo et al., 2009). The net effect of trees on pasture production may be positive or negative depending on the soil fertility, light and water availability (Gea-Izquierdo et al., 2009; Rhoades, 1997). However, negative effects are more frequently reported (Pardini et al., 2010; Marañón and Bartolome, 1994; Barnes et al., 2011; Rivest et al 2013). Due to nutrient competition, Tian et al. (2017) found a reduction on productivity of grasses in the edge of tree-rows in alley cropping systems.

In a wood pasture in Central Italy Pardini et al. (2010) found that annual pasture biomass production at different distances from the tree trunk (at $2.11 \mathrm{~m}$ from the tree trunk, under the tree canopy; at $4.22 \mathrm{~m}$ on the limit of the tree canopy, and at $5 \mathrm{~m}, 10 \mathrm{~m}$, and $20 \mathrm{~m}$ ) was highest at the furthest distance from the tree. They also found that the annual pasture biomass under the tree canopy and at the limit of the tree canopy was $75 \%$ and $84 \%$ of the production at $20 \mathrm{~m}$ respectively.

In addition to affecting total grass production, trees also affect the composition of grass species which in turn, affects the nutritional characteristics of the pasture. Under trees in the dehesa, the presence of herbaceous perennials as well as the ratio of grasses (Poaceae) to legumes (Fabaceae) was higher than that in treeless areas (Puerto Martín et al., 1987; Montoya and Meson, 1982). Trees can also affect the seasonal distribution of pasture growth, and nutritional quality and this will also affect the quantity of pasture consumed by the livestock. Pasture that has not been grazed is available for livestock until the palatability and nutritional characteristics drop below a certain threshold (Pérez-Corona et al., 1998). Thus, extending the duration of suitable nutritional characteristics of the pasture more deeply into the summer and winter periods could potentially have beneficial effects on meeting the daily livestock demand for food. For example, in Spain, the shade provided by tree canopies during the hot summer months can reduce temperatures and evapotranspiration rates and hence the maturation rate of understorey grass. Thus, pasture under trees can be palatable for longer periods than in treeless areas. Furthermore, in cold winters the presence of trees can increase minimum temperatures that reduce the risk of ground frost and extends the growing season of pasture (Gea-Izquierdo et al., 2009; Moreno Marcos et al., 2007). 
However there are also locations and seasons where trees have a negative effect on pasture growth by increasing the competition for water and sunlight (Moreno et al. 2007; Pardini et al., 2010). This has been confirmed in alley cropping systems where the biomass yield of intercropped plants was limited by adjacent trees because of competition for water and light (Miller and Pallardy, 2001; Tian et al., 2015).

These effects of trees on the seasonal distribution of grass growth can vary with region. In Mediterranean pastures grass production is greatest in the spring and autumn-winter period whilst drought restricts growth during the summer. By contrast in wetter regions of North Europe, pasture production can be maintained during summer months whilst low temperatures restrict grass growth during the winter. When the food demand by livestock is greater than the immediate availability of pasture, farmers typically have to provide livestock with supplementary feed such as hay, silage or concentrates. In wood pastures trees can reduce fluctuations in pasture production and thus increase the number of days when pasture is available for livestock.

Trees can also contribute to the food demands of livestock by providing fruit and browse. Hence these components are included in the Forage-SAFE model which was developed to guide the decisions of researchers and advisors in relation to wood pasture management. This paper aims to describe the Forage-SAFE model and then to apply the model for a case study to assess the impact of tree cover density, carrying capacity, and composition of livestock species on wood pasture profitability.

\section{Case study: a modelled dehesa in south-western Spain}

A wood pasture dehesa in south-western Spain was selected as an example to show the applicability of the Forage-SAFE model. The major wood pasture system in South-western Spain is known as dehesa and the equivalent areas in Southern Portugal are known as montado. Dehesas are primarily used for grazing, but they also produce a wide variety of products including firewood, acorns, hunting, mushrooms, cork, and honey (Olea et al., 1990). The area of dehesa and montado in the Iberian Peninsula has been estimated to be around 3.04 million ha (Figure 1).

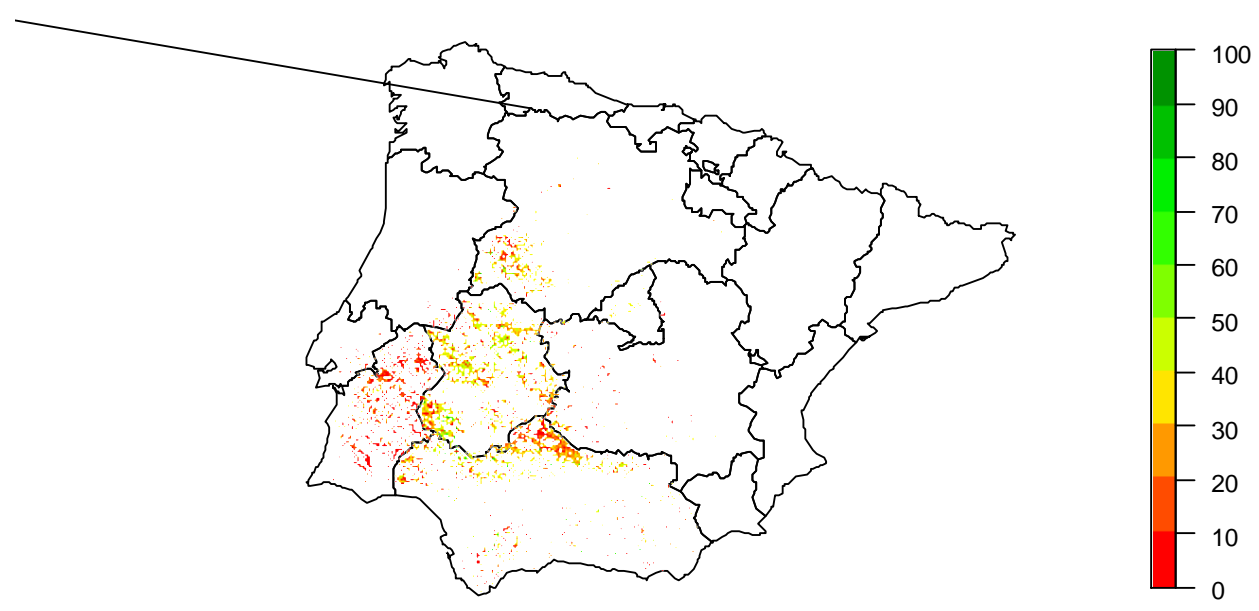

Figure 1. Location and tree cover of dehesa and montado in the Iberian Peninsula. Data used from CORINE Land Cover CLC 2012 and 2012 Tree Cover Density (http://land.copernicus.eu/). 
In general, dehesa farms contain a mix of livestock and tree species, with the most common livestock species being ruminants (cattle, sheep and goats) and Iberian pigs. The main tree species is holm oak (Quercus ilex L. subsp. ballota), followed by cork oak (Quercus suber L.), and Quercus pyrenaica Willd. and Quercus faginea Lam. The average fraction of tree cover in the dehesa regions is around 24\% (estimated in this study from CORINE Land Cover CLC 2012 and 2012 Tree Cover Density from the European Land Monitoring Service, http://land.copernicus.eu/). However, it is estimated that there are over 388,000 ha out of the 3.04 million ha mapped as dehesas that have no trees (over $10 \%$ of the total area of dehesa); the majority of the dehesa (around $93 \%$ of the area) has a tree cover lower than $\mathbf{5 0 \%}$ (Figure 1). Treeless areas are still classified as dehesa, and not pasture, as the treeless areas belonged to dehesa farms in which the whole farm is considered as a dehesa system (Moreno et al 2016).

The typical carrying capacity of the dehesa, i.e. its capacity to support the energy needs of livestock, is relatively low with values between 0.2 and 0.7 Livestock Units (LU) ha ${ }^{-1}$. Dehesas in Extremadura showed a mean carrying capacity of $0.37 \mathrm{LU}_{\mathrm{ha}} \mathrm{H}^{-1}$ (Escribano et al. 2002). Daily grass production changes during the year and farmers often try to adapt the management system (e.g. the timing of calving or lambing) so that the demand of the livestock matches, as far as is possible, the seasonal food availability which is typically high during the spring and low in the dry summer months (Olea et al., 1990).

\section{Methods}

\subsection{Methodological structure of the Forage-SAFE model}

The Forage-SAFE model was developed to determine how the daily balance between food production and the demand for food by livestock affects the annual profitability of wood pastures. The model can be downloaded on the website of a EU FP7 project called "AGroFORestry that Will Advance Rural Development" (AGFORWARD, contract 613520, www.agforward.eu/index.php/es/1828.html). The model identifies food energy deficits and calculates when extra forage, concentrates, fruit or browse are required to meet livestock energy demands. Users can change a large number of parameters including farm structure and alternative forage sources to determine their effect on farm profitability. An optimisation module was developed to identify the combinations of tree cover, carrying capacity and livestock species that maximise production and profitability.

Forage-SAFE is a relatively simple daily time-step dynamic model developed in Microsoft Excel. It contains some macros written in Microsoft Visual Basic for Applications (VBA) to facilitate model use and to run optimization tools to identify locally optimal farm management practices that maximise profitability.

Over 300 variables and parameters can be set in Forage-SAFE to define the biophysical, managerial and economic characteristics of the wood pasture system. The biophysical characteristics include data on pasture, fruit, timber, firewood and browse production. The managerial characteristics include data related to livestock (species, type, age, calendar, weight and consumption), tree (planting, tree protection, pruning, thinning, cutting and browsing) and pasture and fodder crops 
(planting, fertilising, spraying, harvesting and baling). The economic variables include farm costs (variable, fixed, subcontracted labour and rented machinery, and unpaid labour) and revenue (sale of livestock and tree products, and other services).

Forage-SAFE is separated in seven spreadsheets:

1) Biophysical input data: this is the principal spreadsheet where end-users can set biophysical and managerial variables. The annual results are also shown in this sheet. It is divided in three different parts: i) biophysical and managerial input data, ii) the main annual results with links to graphical results, and iii) estimation of 'locally' optimal values of tree cover, carrying capacity and distribution of livestock species to maximise production and profitability.

2) Financial input data: input data on the monetary value of the various components of wood pastures.

3) Graphs: main graphical results including those with a daily time-step.

4) Livestock demand: calculations of daily food and energy demanded from each livestock species (e.g. cows, sheep and pigs) and type (e.g. suckler cow, growing cow and male adult cow).

5) Production NO TREE: calculations of the daily production of pasture and duration of energy content in areas beyond the tree canopy.

6) Production TREE: calculations of the daily production of pasture and duration of energy content in areas under the tree canopy. It also calculates browse and acorn production.

7) Biophysical analysis: calculations of the daily balance between produced and demanded food and resources in the wood pasture.

\subsection{Produced food and resources}

The model is designed so that the primary source of food energy to satisfy livestock demand is the energy contained in pasture, tree browse and fruits. As the available energy changes over time a daily basis framework was needed to assess the balance between produced and demanded food.

\section{Produced energy from the pasture}

The model calculated the energy produced from the pasture (MJ ha ${ }^{-1} \mathrm{~d}^{-1}$ ) as the product of pasture produced in time $t\left(\mathrm{~kg}\right.$ dry matter $\left.(\mathrm{DM}) \mathrm{ha}^{-1} \mathrm{~d}^{-1}\right)$ and the energy content of the pasture $\left(\mathrm{MJ} \mathrm{kg} \mathrm{DM}{ }^{-1}\right)$. The daily balance between pasture production and pasture consumption was calculated for each day, and unconsumed pasture was assumed to be available in subsequent time periods with an updated energy content. The potential change of available energy from pasture ( $A E P$; units: $M J \mathrm{ha}^{-1}$ $\mathrm{d}^{-1}$ ) for day $t$ was calculated using Equation 1:

$$
\frac{d A E P_{t}}{d t}=P P_{t} * E C P+S E P_{t}
$$

where $P P_{t}$ is the dry weight of pasture production on day $t\left(\mathrm{~kg} \mathrm{DM} \mathrm{ha}^{-1} \mathrm{~d}^{-1}\right), E C P$ is the energy content in the pasture $\left(\mathrm{MJ} \mathrm{kg} \mathrm{DM}^{-1}\right)$, and $S E P_{t}$ indicates the surplus of energy from accumulated pasture (MJ $\mathrm{ha}^{-1} \mathrm{~d}^{-1}$ ), i.e. pasture previously produced that had not been consumed.

The value of $\operatorname{SEP}_{t}$ was calculated daily as the difference between pasture production and consumption using Equation 2 where: 


$$
\begin{gathered}
S E P_{t}= \\
S P_{t-1} * E C P * D_{t-1}+ \\
S P_{t-2} * E C P * D_{t-2} * D_{t-1}+ \\
S P_{t-3} * E C P * D_{t-3} * D_{t-2} * D_{t-1}+ \\
\ldots+ \\
S P_{t-n} * E C P * D_{t-n} * D_{t-(n-1)} * D_{t-(n-2)} * D_{t-(n-3)} * \ldots * D_{t-(n-(n-1))}
\end{gathered}
$$

and $S P$ is the surplus from pasture produced in instant $t\left(\mathrm{~kg} \mathrm{DM} \mathrm{ha} \mathrm{h}^{-1} \mathrm{~d}^{-1}\right)$ and $D$ is the pasture senescence coefficient which indicates the retention of energy content over time. The value of $D$ is affected by weather conditions: for example under extreme heat the retention of energy is greater at low temperatures than at high temperatures, e.g. in the summer, and these temperatures can be moderated by the shading effect of the trees.

The model separately calculates the available energy from pasture in treeless areas and areas under tree canopy. Building on Equation 1, which calculates the available energy from pasture in treeless areas, the available energy in areas under a tree canopy $\left(A E P w t_{t}\right)$ is similarly calculated but with the inclusion of a tree density effect (Equation 3 ) using a Gompertz equation.

$$
\frac{d A E P w t_{t}}{d t}=\left(P P w t_{t} *\left(1-e^{\left(-e^{-b *(\delta-C)}\right)}\right)\right) * E C P w t+S E P w t_{t}
$$

where $P P w t_{t}$ is the dry weight of produced pasture, ECPwt is the energy content and $S E P w t_{t}$ is the surplus of energy from accumulated pasture. Pasture production under tree canopy is multiplied by the Gompertz equation where $\delta$ is the proportion of tree cover (between 0 and 1 ) and $b$ and $C$ are constants.

Finally, the available energy from pasture in the system combining treeless areas and areas under tree canopies is calculated as follows:

$$
A E P_{t}=(1-\delta) * A E P w o t_{t}+\delta * A E P w t_{t}
$$

where $\delta$ is the proportional tree cover, $A E P_{\text {wot }}$ is the available energy from pasture in treeless areas and $A E P_{w t}$ is the available energy from pasture in areas under tree canopy. In the modelled dehesa, $3.5 \%$ of the tree cover area was considered to be unproductive in terms of pasture production due to the area occupied by the tree trunks, and the fenced-off or protected areas safeguarding the regeneration of trees.

To derive the daily grass production needed as an input in Forage-SAFE, real data or the output of agroforestry models (e.g. Yield-SAFE (van der Werf et al., 2007; Palma et al., 2016; 2017), Modelo Dehesa (Hernández Díaz-Hambrona et al., 2008; Iglesias et al., 2016) and SPUR2 (Hanson et al., 1994)) can be used. In the dehesa case study, we used data from Daza (1999) in which daily pasture production and energy content in a dehesa in South-western Spain was measured for each month of the year.

\section{Fruit and browse production by the tree}

Fruit and browse were included in the model as sources of food to feed the livestock. A normal probability distribution was used to simulate daily production of fruit within the year comprising three terms: the level of maximum production, the day of the year of highest production, and the standard deviation in terms of number of days. In the modelled dehesa, the fruit was the holm oak acorn. The modelled average acorn production at $40 \%$ tree cover was $354.6 \mathrm{~kg} \mathrm{ha}^{-1}$ between October 
and February. The assumed maximum value of production was $500 \mathrm{~kg} \mathrm{ha}^{-1} \mathrm{yr}^{-1}$, the day of maximum occurrence was on 10 November and the standard deviation was 25 days. Rodríguez-Estévez (2007) stated that mean acorn yield in dehesas in Extremadura range from 300 to $700 \mathrm{~kg} \mathrm{ha}^{-1}$ with a production equivalent to $8-14 \mathrm{~kg}_{\text {tree }}{ }^{-1}$.

Typically in dehesas, Iberian pigs are preferred to ruminants as they are able to benefit from the foraging of the acorns (Rodríguez-Estevez et al., 2009) and the resulting high value added of Iberian pig products. This was included in the model by calculating two energy balances on each day. When acorn availability was greater than demanded by the pigs, the model assumed that ruminants could meet up to $10 \%$ of their daily food demand from the remaining acorns.

Browse from the tree was considered a food source when pasture production did not meet ruminants demand. In the modelled dehesa, browse was assumed to be available when pruning takes place in early February; this is to minimise the impact on acorn production. Pruning costs associated with browsing were considered after the acorns ripened and fell to the ground.

Forage-SAFE also includes other products that can contribute to farm revenues such as timber, firewood, cork, wool and milk. However for the modelled dehesa, it was assumed that all of the farm revenues came from the sale of animals and firewood.

\subsection{Livestock demand for food}

The livestock demand for food at each time increment (DE; units: $M J \mathrm{ha}^{-1} \mathrm{~d}^{-1}$ ) was separately calculated for each species (cattle, sheep and Iberian pigs) and individual according to gender/age category (growing, suckler and male adults) (Equation 5):

$$
D E_{t}=\sum_{s=1}^{3} \sum_{y=1}^{3}\left(n_{t, s, y} * d e_{t, s, y}\right)
$$

where $n_{t, s, y}$ indicated the number of animals in the field and $d e_{t, s, y}$ the energy demand of each animal in the field (MJ animal ${ }^{-1}$ ) at time $t$, for species $s$ and type $y$. Forage-SAFE included two distinct ways to calculate the demanded energy from pasture of each animal. One way was to set the consumption of each animal (DM kg animal ${ }^{-1}$ ) according to specific characteristics such as species, type, weight and physiological state (gestation, lactation and maintenance). The other way was to calculate the demanded energy from pasture using utilised metabolisable energy (UME; units: MJ $\mathrm{LU}^{-1} \mathrm{~d}^{-1}$ ) (see Hodgson, 1990). Hodgson (1990) calculated the UME of a "reference animal" defined as a lactating dairy cow with a live weight $(W)$ of $500 \mathrm{~kg}$ and milk yield $(Y)$ of $10 \mathrm{~kg} \mathrm{~d}^{-1}$ as:

$$
U M E_{t}=8.3+0.091 * W_{t}+4.94 * Y_{t}
$$

where $W_{t}$ and $Y_{t}$ indicated the weight and milk yield respectively in instant $t$.

For Iberian pigs, it was assumed that they would consume between 6.5 and $7.6 \mathrm{~kg}$ of fresh acorns per day (3.1-3.6 kg DM kernel $\mathrm{d}^{-1}$ ) and between 0.38 and $0.49 \mathrm{~kg} \mathrm{DM}$ of pasture depending on the animal's weight (Rodríguez-Estévez et al. 2009).

In the modelled dehesa, the selected carrying capacity was $0.37 \mathrm{LU} \mathrm{ha}^{-1}$ including cattle, sheep and Iberian pigs. It was considered that $38.5 \%$ of the total LU were cattle ( 0.122 growing cows, 0.148 suckler cows and 0.005 male adults per hectare), 39.9\% sheep (1.287 growing sheep, 1.261 suckler 
sheep and 0.048 male adults per hectare) and $21.6 \%$ Iberian pigs ( 0.444 growing pigs per hectare). In the case of the Iberian pig, it was assumed that only growing pigs would be in the field. It was assumed that the new calves and lambs were born in December and February respectively to match the period of maximum pasture production with maximum demand.

\subsection{Assessing the profitability of the wood pasture}

The daily comparison of the energy available in the pasture, browse and fruits and the demand by livestock was used to estimate the requirement for supplementary food as forage, concentrates or acorns to meet the livestock demand. In the modelled dehesa, economic data from the EU Farm Account Data Network (FADN) database (http://ec.europa.eu/agriculture/rica/) and data from personal communication with farmers and experts were used.

Forage-SAFE used three different indicators to assess the profitability of the wood pasture and were calculated as follows:

1) Gross margin: revenue from any product and/or service of the wood pasture (e.g. animal sale, wool, milk, firewood and hunting) plus farming subsidies minus variable costs. Variable costs were separately measured for the livestock (animal purchase, forage and concentrates, veterinary and medicines, bedding and miscellaneous), the crop (seed and plants, fertiliser, crop protection, baling and other costs), and the tree (planting, tree protection, pruning, thinning, cutting and other costs) components. The annual gross margin of the wood pasture was denominated in euros (as of 2016) and expressed per hectare (see Equation 7).

2) Net margin: gross margin minus fixed costs (installation and repairs of infrastructure, fuel and energy, machinery, interest on working capital, and other costs) and paid labour and rented machinery costs (see Equation 8).

3) Net margin including unpaid labour: net margin minus unpaid labour rate times the estimated labour cost (see Equation 9). In the modelled dehesa, the estimated unpaid labour cost was $4.5 € \mathrm{~h}^{-1}$. It could be argued that this cost was too low. However, considering that the opportunity cost of farmers in rural South-western Spain to work off-farm is very low the assumed cost seemed to be reasonable.

\subsection{Estimating optimal managerial decisions in wood pastures}

An important function within Forage-SAFE was the estimation of optimal managerial decisions to maximise gross margin, net margin and net margin including unpaid labour. Thus Forage-SAFE could suggest optimal tree cover, carrying capacity and livestock species composition, assuming that other parameters remained constant. Forage-SAFE used the Generalized Reduced Gradient (GRG) algorithm of the nonlinear Solving method in Microsoft Excel as not all the equations of the model were linear. The GRG algorithm estimated a 'locally' rather than 'globally' optimal solution. This indicated that there was no other set of values for the decision variables close to the current values that yielded a better value for the objective function (maximise production or gross and net margin). Equations 7-9 show the objective function used in Forage-SAFE to maximise annual gross margin $(G M)$, net margin (NM) and net margin including unpaid labour (NM unpaid labour), respectively:

$$
\text { Max. GM }=\sum_{t=1}^{365} \sum_{c=1}^{3} P I_{t, c}+\sum_{t=1}^{365} \sum_{c=1}^{3} S I_{t, c}-\sum_{t=1}^{365} \sum_{c=1}^{3} V C_{t, c}
$$




$$
\begin{aligned}
& \text { Max. } N M=G M-\sum_{t=1}^{365} \sum_{c=1}^{3} F C_{t, c}-\sum_{t=1}^{365} \sum_{c=1}^{3} S C_{t, c} \\
& \text { Max. NM } M_{\text {unpaid labour }}=N M-\sum_{t=1}^{365} \sum_{c=1}^{3} U C_{t, c}
\end{aligned}
$$

where $P I_{t, c}$ is the income from sale products of the component $c$ (livestock, tree and crop) at time $t$. $S I$ is the income from subsidies, $V C$ is the variables cost, $F C$ is the fixed cost, $S C$ is the subcontracted labour and rented machinery cost, and $U C$ is the unpaid labour cost.

\section{Results}

\subsection{Livestock demand for food}

The results for the daily energy demanded for each animal species and type from pasture in the modelled dehesa shows the highest demand for pasture in the dehesa in the spring occurred at the same time as maximum pasture production (Figure 2). On dehesa farms, farmers try to maximise the number of ruminants in the spring and the number of Iberian pigs in late autumn and early winter to coincide with the production of holm oak acorn (Olea et al., 1990).

In the case of cattle and sheep (Figures 2.a and 2.b), the greatest demand for pasture occurred between late February and June, and the growing animals were assumed to be sold before pasture production falls in the summer. For cattle (Figure 2.a), calving was assumed to occur in December, and hence the energy demand of the suckler cows, which started increasing at the end of the gestation stage in November increases when lactation starts. Growing cows and sheep were assumed to be in the field until the age of 6.5 and 3.5 months respectively. In the case of Iberian pigs (Figure 2.c), it was assumed that only growing pigs would be in the field. The figure only shows the demanded energy from pasture. Iberian pigs were in the field for 100 days ( 90 days is the minimum period that Iberian pigs need to be in the field to obtain the premium value of acorn Iberian pork). Finally the total demand for pasture per day in the modelled dehesa was calculated as the sum of the demands of each animal (red line in Figure 2.d, see Equation 5).

\subsection{Food supply for livestock}

The seasonal distribution of the daily energy balance for the pasture and browse (Figure 3a) shows that maximal production occurred between February and early June and to a lesser extent between October and December. The largest surplus of pasture occurred between March and July. Overall, from early August to October and from late November to late January the provision of food energy of the system did not meet livestock demand. Thus farmers would need to use concentrates to satisfy the livestock demand or, as is common practice in the Spanish dehesas, allocate alternative land for producing forage for storage.

From early June to late September pasture production was almost negligible. However, ruminants in this period did not need extra forage or concentrates until August due to the surplus of pasture that was not consumed in the spring. During the spring, pasture production in treeless areas was higher than in areas under tree canopies. However, in early summer the duration of energy content in the surplus of pasture decreased faster in treeless areas than in areas under tree cover. Thus when the pasture was dry with very low energy content in treeless areas, under the tree canopy the 
accumulated pasture was still fresh and provided a source of food for the livestock. This allowed the extension of the period when external feed was not required. In a similar way but to a lesser extent, this also occurred in the winter where the tree canopy protected the pasture from frosts and thereby the pasture retained its energy content for longer.

a)

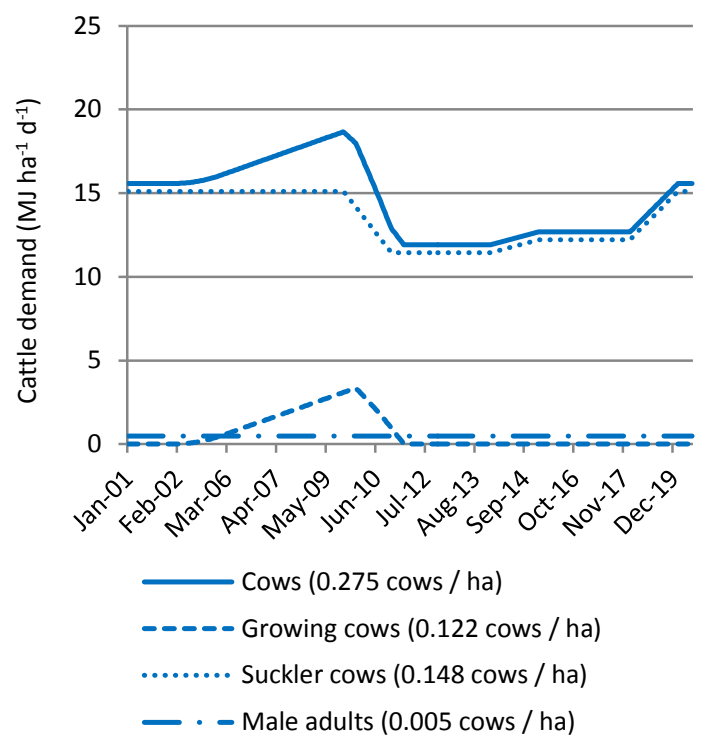

c)

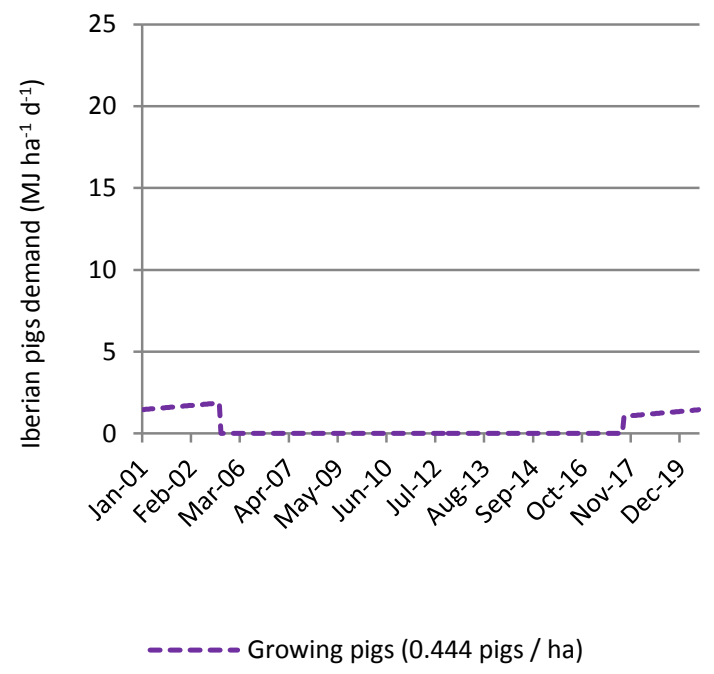

b)

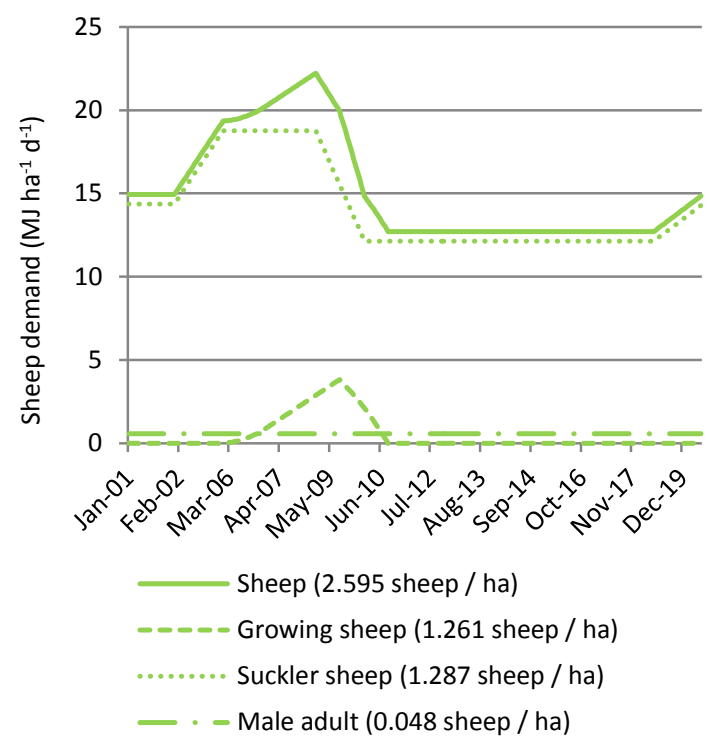

d)

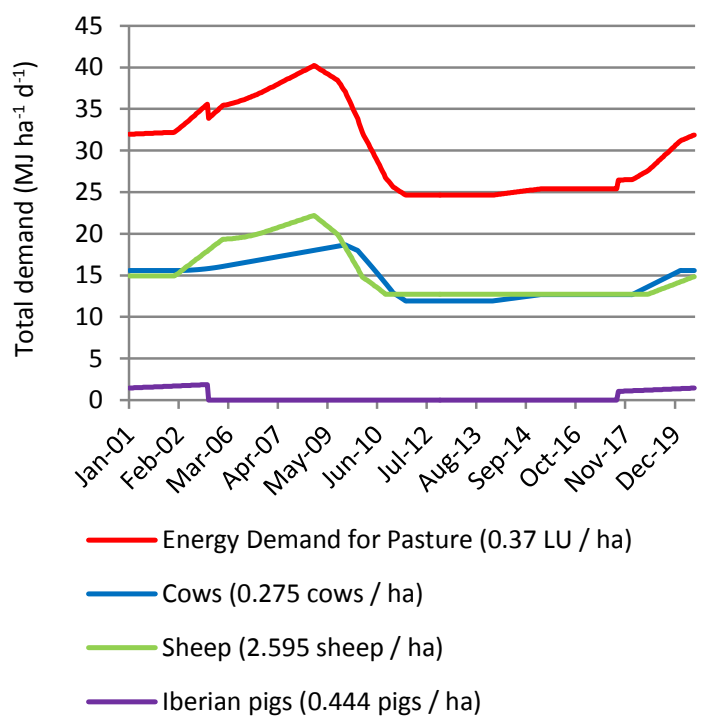

Figure 2. Seasonal (January to December) energy demand from pasture in the dehesa for 2.a) cattle, b) sheep, c) growing pigs, and d) the combination of each of the above.

Browse was used to feed ruminants in late January and this met some of the demand for pasture. The timing of Iberian pigs in the field from November to February coincided with the period of maximal acorn production (Figure $3 \mathrm{~b}$ ). It was assumed that pigs would have priority to eat acorns 
over ruminants, i.e. the ruminants would only eat acorns if pigs had previously satisfied their demand for acorns. Thus most acorns were used to feed the lberian pigs.

a)

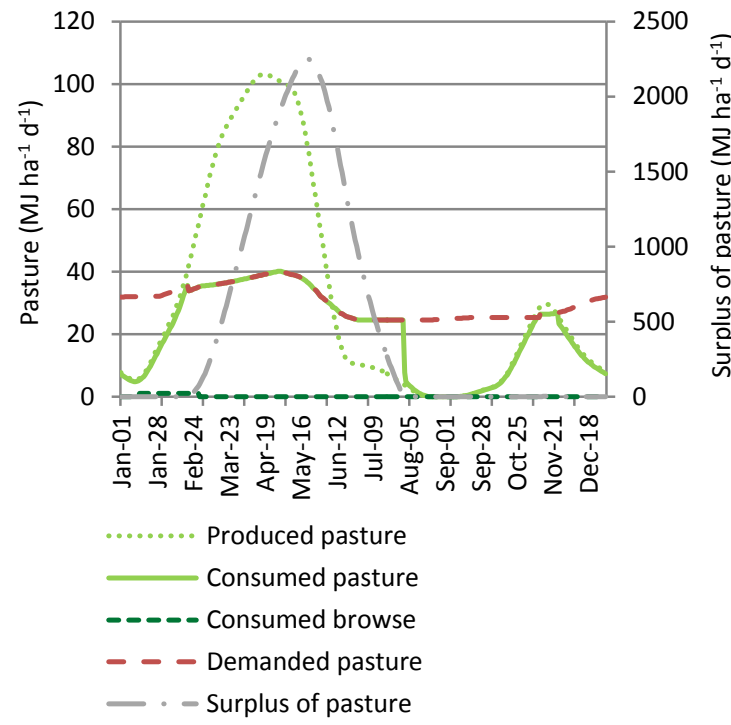

b)

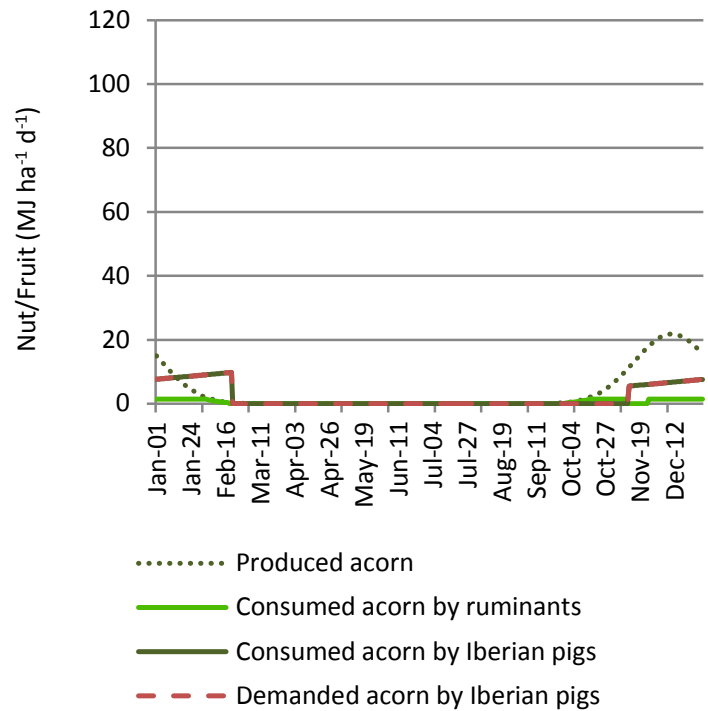

Figure 3. Produced (dotted lines), consumed (continuous lines), surplus (dashed and dotted line) and demanded (dashed lines) energy from a) pasture, browse and b) acorn in the dehesa case study at 0.37 LU ha $^{-1}$ (39.9\% sheep, $38.5 \%$ cattle and $21.6 \%$ Iberian pigs).

An analysis of the annual food production, consumption and extra requirements of the modelled dehesa at a carrying capacity $0.37 \mathrm{LU} \mathrm{ha}^{-1}$ (under different tree cover densities) showed that maximum annual pasture production was obtained at $0 \%$ tree cover (1465 $\mathrm{kg} \mathrm{DM} \mathrm{ha}^{-1}$ ) (Table 1). Annual pasture production decreased as tree cover increased. By contrast acorn production increased as tree cover increased up to $70 \%$ tree cover beyond which point tree competition reduced acorn production.

The lower half of Table 1 shows annual consumption and extra requirements for a dehesa: i) with and ii) without Iberian pigs. Pasture consumption reached the maximum value at $30 \%$ tree cover in both situations reaching $876 \mathrm{~kg} \mathrm{DM} \mathrm{ha}^{-1}$ in the case of Iberian pigs and $1007 \mathrm{~kg} \mathrm{DM} \mathrm{ha}^{-1}$ without Iberian pigs. Browse consumption also increased as tree cover increased. Acorn consumption was maximal at $80 \%$ with Iberian pigs $\left(285 \mathrm{~kg} \mathrm{ha}^{-1}\right)$ and at $70 \%$ without lberian pigs ( $\left.103 \mathrm{~kg} \mathrm{ha}^{-1}\right)$.

The annual quantity of extra forage and acorn needed to meet the livestock demand was also estimated. The lowest requirement for forage was $375 \mathrm{~kg} \mathrm{DM} \mathrm{ha}^{-1}$ in a dehesa with Iberian pigs at $50 \%$ tree cover and $559 \mathrm{~kg} \mathrm{DM} \mathrm{ha}^{-1}$ without Iberian pigs at $40 \%$ tree cover. Compared to the maximum value, in a treeless dehesa the forage needed increased by around $9 \%$ with and without Iberian pigs. In regards to acorn needs, from a $40 \%$ tree cover onwards there was no need to meet the Iberian pigs demand for acorns. 
Table 1. Annual generated products and supplementary needs to satisfy livestock demand ( 0.37 LU $\mathrm{ha}^{-1}$ ) in dehesa under different tree cover densities. Bold and underlined figures indicate the best and worst values from a financial perspective, respectively.

\begin{tabular}{|c|c|c|c|c|c|c|c|c|c|c|c|}
\hline \multirow{2}{*}{ Indicator } & \multicolumn{11}{|c|}{ Tree cover (\%) } \\
\hline & 0 & 10 & 20 & 30 & 40 & 50 & 60 & 70 & 80 & 90 & 100 \\
\hline \multicolumn{12}{|l|}{ Production } \\
\hline Pasture (kg DM ha ${ }^{-1}$ ) & 1465 & 1431 & 1397 & 1364 & 1328 & 1279 & 1181 & 1010 & 781 & 529 & 281 \\
\hline Acorns (kg ha $\left.{ }^{-1}\right)$ & $\underline{0}$ & 90 & 179 & 269 & 352 & 424 & 475 & 499 & 495 & 466 & 424 \\
\hline \multicolumn{12}{|c|}{ With Iberian pigs (cattle $=0.14 \mathrm{LU}_{\text {ha }}^{-1}$, sheep $=0.15 \mathrm{LU} \mathrm{ha}^{-1}$, Iberian pigs $=0.08 \mathrm{LU}_{\mathrm{ha}}{ }^{-1}$ ) } \\
\hline \multicolumn{12}{|l|}{ Consumption } \\
\hline Pasture (kg DM ha ${ }^{-1}$ ) & 874 & 875 & 876 & 876 & 875 & 870 & 848 & 799 & 705 & 502 & $\underline{267}$ \\
\hline Browse (kg DM ha ${ }^{-1}$ ) & $\underline{0}$ & 3 & 5 & 8 & 10 & 13 & 15 & 18 & 21 & 23 & 26 \\
\hline Acorns $\left(\mathrm{kg} \mathrm{ha}^{-1}\right)$ & $\underline{0}$ & 63 & 126 & 188 & 241 & 276 & 284 & 285 & 285 & 284 & 277 \\
\hline \multicolumn{12}{|l|}{ Extra supplementary needs } \\
\hline Forage needed $\left(\mathrm{kg} \mathrm{DM} \mathrm{ha}{ }^{-1}\right)$ & 408 & 406 & 405 & 403 & 385 & 375 & 390 & 436 & 528 & 730 & $\underline{967}$ \\
\hline Acorns needed $\left(\mathrm{kg} \mathrm{ha}^{-1}\right)$ & $\underline{201}$ & 138 & 75 & 13 & 0 & 0 & 0 & 0 & 0 & 0 & 0 \\
\hline \multicolumn{12}{|c|}{ Without Iberian pigs (cattle $=0.18 \mathrm{LU} \mathrm{ha}^{-1}$, sheep $=0.19 \mathrm{LU} \mathrm{ha}^{-1}$ ) } \\
\hline \multicolumn{12}{|l|}{ Consumption } \\
\hline Pasture (kg DM ha ${ }^{-1}$ ) & 1005 & 1006 & 1007 & 1008 & 1007 & 1001 & 972 & 901 & 742 & 502 & $\underline{267}$ \\
\hline Browse (kg DM ha ${ }^{-1}$ ) & $\underline{0}$ & 3 & 5 & 8 & 10 & 13 & 15 & 18 & 21 & 23 & 26 \\
\hline Acorns (kg ha ${ }^{-1}$ ) & $\underline{0}$ & 41 & 79 & 91 & 96 & 100 & 102 & 103 & 103 & 102 & 100 \\
\hline \multicolumn{12}{|l|}{ Extra supplementary needs } \\
\hline Forage needed (kg DM ha $\left.{ }^{-1}\right)$ & 610 & 589 & 570 & 563 & 559 & 562 & 588 & 657 & 815 & 1053 & 1288 \\
\hline Acorns needed $\left(\mathrm{kg} \mathrm{ha}^{-1}\right)$ & 0 & 0 & 0 & 0 & 0 & 0 & 0 & 0 & 0 & 0 & 0 \\
\hline
\end{tabular}

\subsection{Tree cover impact on profitability}

Forage-SAFE was designed to allow the assessment of the impact of different tree cover densities on the profitability of the wood pasture. Table 2 shows the gross margin, net margin and net margin including unpaid labour in the modelled dehesa, and the percentages show the relative change compared to the maximum value. With Iberian pigs, the highest profitability was achieved at $40 \%$ tree cover $\left(G M=179 € \mathrm{ha}^{-1}, N M=72 € \mathrm{ha}^{-1}\right.$ and $\left.N M_{\text {including unpaid labour }}=35 € \mathrm{ha}^{-1}\right)$. Without lberian pigs, the highest profitability was achieved at $20 \%$ tree cover $\left(G M=128 € \mathrm{ha}^{-1}, N M=43 € \mathrm{ha}^{-1}\right.$ and $N M_{\text {including unpaid labour }}=28 €$ ha $^{-1}$ ). It is worth highlighting that the net margin including unpaid labour in a treeless dehesa without Iberian pigs was $8 \%$ lower than at $20 \%$ tree cover. 
Table 2. Profitability of dehesa under different tree cover densities. Percentage values show the relative reduction compared to the maximum value in each indicator. Bold and underlined figures indicate the best and worst values from a financial perspective within each scenario, respectively.

\begin{tabular}{|c|c|c|c|c|c|c|c|c|c|c|c|}
\hline \multirow[t]{2}{*}{ Profitability indicator } & \multicolumn{11}{|c|}{ Tree cover (\%) } \\
\hline & 0 & 10 & 20 & 30 & 40 & 50 & 60 & 70 & 80 & 90 & 100 \\
\hline \multicolumn{12}{|c|}{ With Iberian pigs (cattle $=0.14 \mathrm{LU} \mathrm{ha}^{-1}$, sheep $=0.15 \mathrm{LU} \mathrm{ha}^{-1}$, Iberian pigs $=0.08 \mathrm{LU}_{\mathrm{ha}}{ }^{-1}$ ) } \\
\hline \multirow{2}{*}{$\begin{array}{l}\text { Gross margin } \\
\left(€ \mathrm{ha}^{-1}\right)\end{array}$} & 106 & 129 & 153 & 175 & 179 & 177 & 175 & 173 & 159 & 120 & $\underline{74}$ \\
\hline & $-41 \%$ & $-28 \%$ & $-15 \%$ & $-2 \%$ & $0 \%$ & $-1 \%$ & -2 & $-3 \%$ & $-11 \%$ & $-33 \%$ & $-58 \%$ \\
\hline \multirow{2}{*}{$\begin{array}{l}\text { Net margin } \\
\left(€ h a^{-1}\right)\end{array}$} & -1 & 23 & 46 & 69 & 72 & 70 & 08 & 66 & 52 & 13 & -33 \\
\hline & $-101 \%$ & $-69 \%$ & $-36 \%$ & $-4 \%$ & $0 \%$ & $-3 \%$ & $-6 \%$ & $-8 \%$ & $-27 \%$ & $-82 \%$ & $-146 \%$ \\
\hline \multirow{2}{*}{$\begin{array}{l}\text { Net margin including } \\
\text { unpaid labour }\left(€ \mathrm{ha}^{-1}\right)\end{array}$} & -35 & -12 & 10 & 33 & 35 & 33 & 30 & 28 & 14 & -26 & -72 \\
\hline & $-198 \%$ & $-134 \%$ & $-70 \%$ & $-7 \%$ & $0 \%$ & $-7 \%$ & $-14 \%$ & $-22 \%$ & $-61 \%$ & $-174 \%$ & $-305 \%$ \\
\hline \multicolumn{12}{|c|}{ Without Iberian pigs (cattle $=0.18 \mathrm{LU} \mathrm{ha}^{-1}$, sheep $=0.19 \mathrm{LU} \mathrm{ha}^{-1}$ ) } \\
\hline \multirow{2}{*}{$\begin{array}{l}\text { Gross margin } \\
\left(€ \mathrm{ha}^{-1}\right)\end{array}$} & 124 & 126 & 128 & 127 & 126 & 123 & 117 & 102 & 71 & 24 & $\underline{-21}$ \\
\hline & $-3 \%$ & $-1 \%$ & $0 \%$ & $-1 \%$ & $-2 \%$ & $-4 \%$ & $-9 \%$ & $-20 \%$ & $-45 \%$ & $-81 \%$ & $\underline{-116 \%}$ \\
\hline \multirow{2}{*}{$\begin{array}{l}\text { Net margin } \\
\left(€ \mathrm{ha}^{-1}\right)\end{array}$} & 39 & 41 & 43 & 42 & 41 & 38 & 31 & 16 & -15 & -61 & -106 \\
\hline & $-8 \%$ & $-4 \%$ & $0 \%$ & $-2 \%$ & $-5 \%$ & $-11 \%$ & $-27 \%$ & $-61 \%$ & $-135 \%$ & $-243 \%$ & $-350 \%$ \\
\hline \multirow{2}{*}{$\begin{array}{l}\text { Net margin including } \\
\text { unpaid labour }\left(€ \mathrm{ha}^{-1}\right)\end{array}$} & 25 & 26 & 28 & 26 & 24 & 21 & 14 & -1 & -33 & -80 & $\underline{-126}$ \\
\hline & $-8 \%$ & $-4 \%$ & $0 \%$ & $-4 \%$ & $-11 \%$ & $-23 \%$ & $-49 \%$ & $-105 \%$ & $-220 \%$ & $-390 \%$ & $-556 \%$ \\
\hline
\end{tabular}

Lastly the locally optimal tree cover, carrying capacity and livestock species composition that maximised the gross margin, net margin and net margin including unpaid labour costs in the modelled dehesa were calculated (Table 3 ). These values were locally optimal for the parameter values in the modelled dehesa which had a tree cover of $40 \%$ and a carrying capacity of $0.37 \mathrm{LU} \mathrm{ha}^{-1}$ from which $38.5 \%$ corresponded to cattle, $39.9 \%$ to sheep, and $21.6 \%$ to Iberian pigs. The results showed that, keeping all other parameters constant, profitability was maximised at about $32 \%$ tree cover. The carrying capacity values that maximised profitability ranged between $0.40 \mathrm{LU} \mathrm{ha}^{-1}$ and $0.46 \mathrm{LU} \mathrm{ha}^{-1}$. The gross and net margins were maximised when Iberian pigs comprised between $9.8 \%$ and $26.7 \%$ of the overall livestock units.

The last three rows of the table showed the optimal simultaneous combination of tree cover, carrying capacity, and livestock species composition. The estimated gross and net margins were higher than those estimated when only one variable was changed in the optimisation problem. This reflects the economic effect of combining these managerial decisions. The optimal combination that maximised the net margin including unpaid labour had a tree cover of $53.1 \%$ and a carrying capacity of $0.44 \mathrm{LU} \mathrm{ha}^{-1}$ of which $71.9 \%$ were ruminants and $28.1 \%$ Iberian pigs. The maximum net margin including unpaid labour in the modelled dehesa was 52 Euros ha ${ }^{-1}$. 
Table 3. Locally optimal values of tree cover, carrying capacity and livestock species composition that maximise farm gross margin (GM), net margin (NM) and net margin including unpaid labour costs (NM unpaid labour). The default values of the modelled dehesa were a tree cover density $28 \%$ and a carrying capacity $0.37 \mathrm{LU} \mathrm{ha}^{-1}$ from which $78.4 \%$ were ruminants $\left(0.28\right.$ cows and 2.60 sheep ha $\left.{ }^{-1}\right)$ and $21.6 \%$ Iberian pigs $\left(0.44\right.$ pigs ha $\left.^{-1}\right)$.

\begin{tabular}{|c|c|c|c|c|c|}
\hline \multirow[b]{2}{*}{ Objective function } & \multirow{2}{*}{$\begin{array}{l}\text { Tree } \\
\text { cover } \\
(\%)\end{array}$} & \multirow{2}{*}{$\begin{array}{l}\text { Carrying } \\
\text { capacity } \\
\left(\text { LU ha }{ }^{-1}\right)\end{array}$} & \multicolumn{2}{|c|}{ Livestock species composition } & \multirow{2}{*}{$\begin{array}{l}\text { Margin } \\
\left(€ \text { ha }^{-1}\right)\end{array}$} \\
\hline & & & $\begin{array}{l}\text { Ruminants } \\
\left(\% \text { LU ha }^{-1}\right)\end{array}$ & $\begin{array}{l}\text { Iberian pigs } \\
(\% \text { LU ha-1) }\end{array}$ & \\
\hline \multicolumn{6}{|l|}{ Optimal tree cover } \\
\hline Max. GM & 32.1 & - & - & - & 180 \\
\hline Max. NM & 32.1 & - & - & - & 73 \\
\hline Max. NM unpaid labour & 32.1 & - & - & - & 37 \\
\hline \multicolumn{6}{|c|}{ Optimal carrying capacity } \\
\hline Max. GM & - & 0.46 & - & - & 196 \\
\hline Max. NM & - & 0.41 & - & - & 86 \\
\hline Max. $N M_{\text {unpaid labour }}$ & - & 0.41 & - & - & 48 \\
\hline \multicolumn{6}{|c|}{ Optimal livestock species composition } \\
\hline Max. GM & - & - & 26.7 & 73.3 & 189 \\
\hline Max. NM & - & - & 26.7 & 73.3 & 77 \\
\hline Max. NM unpaid labour & - & - & 9.8 & 90.2 & 40 \\
\hline \multicolumn{6}{|c|}{ Optimal combination of tree cover, carrying capacity and livestock species composition } \\
\hline Max. GM & 61.8 & 0.44 & 30.6 & 69.4 & 225 \\
\hline Max. NM & 55.9 & 0.44 & 29.2 & 70.8 & 103 \\
\hline Max. NM unpaid labour & 53.1 & 0.44 & 28.1 & 71.9 & 53 \\
\hline
\end{tabular}

\section{Discussion}

Forage-SAFE has some limitations that should be taken into account. Firstly, some of the input parameters could not be easily obtained or varied substantially throughout time, and the calculation of the farm net margin can be very sensitive to these parameters. For example, the price of the live weight of the animals affects the estimation of optimal carrying capacity and livestock species composition. Since livestock prices can be volatile, the results can vary greatly between years. Secondly, the rate of decrease of the energy content in pasture can be difficult to model and validate with real data. In Forage-SAFE, the value of the pasture senescence coefficient $(D)$ varied with daily weather data and considered microclimatic effects determined by the interaction between the tree and the pasture. In the Mediterranean dehesa, the coefficient should have lower values in summer when the nutritional value of the pasture decreases quickly as a result of drought. Thirdly, within the model it is assumed that the farm administrative costs are independent of the tree cover. However in practice a farmer may need to spend time categorising the different levels of tree cover across a farm when claiming support from the European Union Common Agricultural Policy. Fourthly, the model assumed a steady state in terms of the maturity and density of the trees and did not simulate a whole tree rotation. Thus there were some revenues and costs that were not considered in the economic analysis. However, the rotation of wood pastures is often very long which makes it difficult to model all the costs and benefits incurred in the past. In the case of the dehesa, the rotation of holm oak is often around 180-250 years (Montoya, 1989; Olea and San Miguel-Ayanz, 2006) and sometimes the origin of the dehesa is associated with clearing of the trees in holm oak forests (San Miguel, 1994). In order to solve these issues, Forage-SAFE calculates costs that are not annually undertaken (e.g., planting, pruning and thinning costs) by using the frequency of the operation 
during the rotation. Despite these challenges, Forage-SAFE provides a systematic means of quantifying the effect of trees on pasture production and the impact of managerial decisions on the economics of wood pasture systems.

The results in the modelled dehesa showed that trees could provide an important supply of food in terms of forage resources and buffer the challenges created by the strong seasonality of pasture growth. In terms of forage resources, the results showed that for the modelled dehesa farm, $40 \%$ tree cover provided the maximum metabolisable energy. This metabolisable energy was provided by the pasture, browse and acorns. Although at this tree cover, neither the production of pasture, browse, or acorns was maximised, the combined metabolisable energy production of all three together, was greater than at any other tree cover density. In terms of buffering the strong seasonality of pasture growth, the results showed that despite lowering annual pasture production, the presence of trees can increase pasture consumption. Annual pasture production was maximised at $0 \%$ tree cover. However, despite producing $9 \%$ less grass than at $0 \%$ tree cover, the maximum pasture consumption was reached at a tree cover of around $30 \%$ both with Iberian pigs (an increase of $0.2 \%$ in comparison with $0 \%$ tree cover) and without lberian pigs (an increase of $0.3 \%$ in comparison with $0 \%$ tree cover). This was because the trees helped to maintain the nutritional characteristics of the pasture for longer periods of time, particularly in summer and winter. These results indicate that even if there are no Iberian pigs in the dehesa, trees will still have a positive effect on the profitability of the system. It is worth highlighting that over $10 \%$ of the total area of dehesa and montado in the Iberian Peninsula has a tree cover density lower than 10\% (Figure 1). Thus our results suggest that profitability of Iberian dehesas and montados could be increased by increasing tree cover density, since higher levels of metabolisable energy would be produced and consumed at higher tree cover densities.

Pasture production under the tree canopy was calculated to be around $77 \%$ of the production in treeless areas. Approximately 3.5\% of the tree cover area was considered unproductive due to the area occupied by the trunk and any fenced off or protected areas protecting the regeneration of trees. Several studies have shown that annual grass production under tree canopies is usually lower than in areas without trees (e.g. Marañón and Bartolome, 1994, Pardini et al., 2010 and Barnes et al., 2011). These studies have found an annual reduction of pasture production under tree canopies of $75-100 \%$ compared to treeless areas. The extent of the variation depends on a number of factors such as climate, slope, orientation, and tree and grass species. Some studies have highlighted that higher latitudes and colder climates can lead to a lower relative yield (Silva-Pando et al., 2002; Pardini et al., 2010) than in Iberian dehesas (Moreno et al., 2007; Gea-Izquierdo et al., 2009). Moreover, extrapolating a reliable estimation of pasture production in scattered trees wood pastures is difficult and Rivest et al. (2013) and Mazía et al. (2016) show that, on average, the net effect of the trees on pasture understory is almost neutral although there is high spatio-temporal variability. The meta-analysis in Rivest et al. (2013) shows that the net effect depends on tree traits (e.g. deciduous vs evergreen; legumes vs non-legumes), climate, temporal distribution of rainfall and soil fertility. Recent advances in agroforestry modelling (e.g. van der Werf et al., 2007 and Iglesias et al., 2016) could help provide more robust data to use with the Forage-SAFE model. The increasing reliability of satellite data for estimating pasture productivity also provides opportunities to use such data for individual farms (e.g. Ali et al., 2016). 
Only provisioning ecosystem services (production of pasture, browse, acorn and firewood) were included as sources of revenue in this assessment. A wider economic analysis, from a societal perspective, could also include a range of non-marketed ecosystem services and this is likely to increase the estimates of optimal tree cover density. For example, including the value of regulating and cultural services such as carbon sequestration, biodiversity, recreation and landscape values, would increase the value of the trees, and in turn the optimal tree density in the landscape. Some studies have measured the beneficial effect of trees in increasing soil organic carbon (Howlett et al., 2011) and described benefits to biodiversity (Moreno et al., 2016), and cultural services such as recreation and landscape aesthetic (Fagerholm et al., 2016). The RECAMAN project has recently evaluated the monetary value of provisioning, regulating and cultural services of Iberian dehesas (Campos et al., 2014; Ovando et al., 2015). The profitability of trees in dehesas could also be increased by including agri-environment subsidies that can be available for afforestation of agricultural land (since 1992) or the establishment and maintenance of agroforestry (since 2007) (European Commission, 2013).

\section{Conclusions}

This paper describes a bio-economic model, Forage-SAFE, and its application to determine the impact of tree cover on the management and economics of wood pasture systems using a dehesa case study. The model quantified the energy demanded by livestock and the energy provided by the system using a daily time-step. Using the model, we calculated how much extra forage was needed to satisfy the livestock feeding requirements and included this cost in the profitability assessments. Using current costs and benefits, the results demonstrate that the trees in dehesas provide a net financial benefit and it is possible to identify an optimal tree cover density. The results showed that the highest annual pasture production was achieved at $0 \%$ tree cover. However, considering pasture, browse, and acorns together the production of metabolisable energy was maximised at a tree cover density of around $40 \%$. At a typical stocking density of $0.37 \mathrm{LU} \mathrm{ha-1}$, the maximum net margin, including unpaid labour as a cost to the farmer, was obtained at a tree cover density of around $32 \%$. This increased as carrying capacity and the proportion of Iberian pigs was increased. These results suggest that a daily time-step modelling approach based on the practical challenges of managing varying livestock demand for metabolisable energy and varying pasture production is needed for quantifying the economic impact that trees have on buffering the strong seasonality of pasture growth.

\section{Acknowledgements}

We acknowledge support of the European Commission through the AGFORWARD FP7 research project (contract 613520). Also the Forest Research Center strategic project (PEst OE/AGR/UI0239/2014) and the Portuguese Foundation for Science and Technology (SFRH/BD/52691/2014).

\section{References}

Ali, I., Cawkwell, F., Dwyer, E., Barrett, B., Green, S., 2016. Satellite remote sensing of grasslands: from observation to management-a review. J. Plant Ecol. 9 (6), 649-671. 
Barnes, P., Wilson, B.R., Trotter, M.G., Lamb, D.W., Reid, N., Koen, T., Bayerlein, L., 2011. The patterns of grazed pasture associated with scattered trees across an Australian temperate landscape: an investigation of pasture quantity and quality. The Rangeland Journal 33, 121-130.

Bergmeier, E., Petermann, J., Schröder, E., 2010. Geobotanical survey of wood-pasture habitats in Europe: diversity, threats and conservation. Biodivers. Conserv.19 (11), 2995-3014.

Campos, P., Caparrós, A., Beguería, S., Carranza, J., Díaz-Balteiro, L., Díaz, M., Ovando, P., 2014. RECAMAN: Manufactured and environmental total incomes of Andalusian forest. CSIC, Madrid, Spain.

Daza, A., 1999. Producción de vacuno de carne en la dehesa. Bovis, 87.

den Herder, M., Moreno, G., Mosquera-Losada, R.M., Palma, J.H.N., Sidiropoulou, A., Santiago Freijanes, J.J., Crous-Duran, J., Paulo, J.A., Tomé, M., Pantera, A., Papanastasis, V.P., Mantzanas, K., Pachana, P., Papadopoulos, A., Plieninger, T., Burgess, P.J., 2017. Current extent and stratification of agroforestry in the European Union. Agriculture, Ecosystems and Environment 241, 121-132.

Escribano, M., A. Rodríguez de Ledesma, F.J. Mesías, Pulido, F., (2002). Stocking rate levels in dehesa systems of Extremadura (south-west of Spain). Arch. Zootec. 51, 315-326.

European Commission (2013) REGULATION (EU) No 1305/2013 of the European parliament and of the council of 17 December 2013 on support for rural development by the European Agricultural Fund for Rural Development (EAFRD). Available at: http://eurlex.europa.eu/LexUriServ/LexUriServ.do?uri=OJ:L:2013:347:0487:0548:en:PDF.

Fagerholm, N., Oteros-Rozas, E., Raymond, C. M., Torralba, M., Moreno, G., Plieninger, T., 2016. Assessing linkages between ecosystem services, land-use and well-being in an agroforestry landscape using public participation GIS. Appl. Geogr. 74, 30-46.

Gea-Izquierdo, G., Montero, G., Canellas, I., 2009. Changes in limiting resources determine spatiotemporal variability in tree-grass interactions. Agrofor. Syst. 76(2), 375-387.

García de Jalón, S., Graves, A., Palma, J.H.N., Williams, A., Upson, M., Burgess, P.J., 2018. Modelling and valuing the environmental impacts of arable, forestry and agroforestry systems: a case study. Agrofor. Syst. (in press). DOI: 10.1007/s10457-017-0128-z.

Graves, A.R., Burgess, P.J., Liagre, F., Terreaux, J.-P., Borrel, T., Dupraz, C., Palma, J., Herzog, F., 2011. Farm-SAFE: the process of developing a plot- and farmscale model of arable, forestry, and silvoarable economics. Agrofor. Syst. 81, 93-108.

Hanson, J.D., Baker, B.B., Bourdon, R.M., 1994. Documentation and users guide for SPUR2. GPSR Technical Report No. 1. USDA Agricultural Research Service, Great Plains Systems Research Unit, Ft. Collins, CO.

Hernández Díaz-Ambrona, C., Etienne, A., Martínez Valderrama, J., 2008. Producciones potenciales de herbáceas, de bellota y carga ganadera en las dehesas de Extremadura. Pastos 38 (2), 243 258.

Hodgson, J., 1990. Grazing Management: Science into Practice. Volume 4 of Longman handbooks in agriculture Longman Scientific \& Technical. University of Michigan. 203 pp.

Howlett, D.S., Moreno, G., Mosquera-Losada, M.R., Nair, P.K.R., Nair, V.D., 2011. Soil carbon storage as influenced by tree cover in the Dehesa cork oak silvopasture of central-western Spain. J. Environ. Monit. 13, 1897-1904.

Iglesias, E., Báez, K., Diaz-Ambrona, C. H., 2016. Assessing drought risk in Mediterranean Dehesa grazing lands. Agric. Syst. 149, 65-74. 
López-Díaz, M. L., Rolo, V., Benítez, R., \& Moreno, G., 2015. Shrub encroachment of Iberian dehesas: implications on total forage productivity. Agrofor. Syst. 89(4), 587-598.

Marañón, T., Bartolome, J.W., 1994. Coast live oak (Quercus agrifolia) effects on grassland biomass and diversity. Madroño 41, 39-52.

Mazía, N., Moyano, J., Perez, L., Aguiar, S., Garibaldi, L. A., \& Schlichter, T., 2016. The sign and magnitude of tree-grass interaction along a global environmental gradient. Global. Ecol. Biogeogr. 25(12), 1510-1519.

Miller, A.W., Pallardy, S.G., 2001. Resource competition across the crop-tree interface in a maizesilver maple temperate alley cropping stand in Missouri. Agrofor. Syst. 53 (3), 247-259.

Montoya, J.M., 1989. Encinas y encinares. Mundiprensa. Madrid. 131 pp.

Montoya, J.M., Meson, M.L., 1982. Intensidad y efectos de la influencia del arbolado de las dehesas sobre la fenología y composición específica del sotobosque. Anales del Instituto Nacional de Investigaciones Agrarias. Serie Forestal 523, 43-59.

Moreno, G., Gonzalez-Bornay, G., Pulido, F., Lopez-Diaz, M. L., Bertomeu, M., Juárez, E., Diaz, M., 2016. Exploring the causes of high biodiversity of Iberian dehesas: the importance of wood pastures and marginal habitats. Agrofor. Syst. 90(1), 87-105.

Moreno, G., Obrador, J. J., Garcia, A., 2007. Impact of evergreen oaks on soil fertility and crop production in intercropped dehesas. Agric. Ecosyst. Environ. 119, 270-280.

Moreno Marcos G., Obrador, J.J., García, E., Cubera, E., Montero, M.J., Pulido, F., Dupraz, C., 2007. Driving competitive and facilitative interactions in oak dehesas through management practices. Agroforest Syst 70, 25-40.

Moreno, G., Pulido, F.J., 2009. The functioning, management and persistence of dehesas. In Agroforestry in Europe (pp. 127-160). Springer Netherlands.

Olea, L., Paredes, J., Verdasco, M.A P., 1990. Características y producción de los pastos de las dehesas del S. O. de la Península Ibérica. Pastos 20-21 (1-2), 131-156.

Olea, L., San Miguel-Ayanz, A., 2006. The Spanish dehesa. A traditional Mediterranean silvopastoral system linking production and nature conservation. Grassl. Sci. Eur. 11, 3-13.

Ovando, P., Campos, P., Oviedo, J.L., Caparrós, A., 2015. Private and public incomes in dehesas and coniferous forests in Andalusia, Spain. In: Standiford, Richard B.; Purcell, Kathryn L., tech. cords. Proceedings of the seventh California oak symposium: managing oak woodlands in a dynamic world. Gen. Tech. Rep. PSW-GTR-251. Berkeley, CA, U.S. Department of Agriculture, Forest Service, Pacific Southwest Research Station: 241-250.

Palma, J.H.N., Graves, A.R., Crous-Duran J, Upson, M., Paulo, J.A., Oliveira, T.S., Silvestre Garcia de Jalón, S., Burgess, P.J. (2016). Yield-SAFE Model Improvements. Milestone Report 29 (6.4) for EU FP7 Research Project: AGFORWARD 613520. (5 July 2016). 30 pp.

Palma, J.H.N., Graves, A.R., Crous-Duran, J., García de Jalón, S., Oliveira, T.S., Paulo, J.A., FerreiroDomínguez, N., Moreno, G., Burgess, P.J., 2017. EcoYield-SAFE: maintaining a parameter-sparse approach in modelling silvopastoral systems. Submitted to Ecological Modelling.

Pardini, A., Mori, S., Rigueiro-Rodríguez, A., Mosquera-Losada, M.R., 2010. Efecto del arbolado en la producción de pasto y trigo (Triticum aestivum L.) ecológicos en la maremma Toscana (Italia central). Pastos: Revista de la Sociedad Española para el Estudio de los Pastos 40 (2), 211-223.

Pérez-Corona, M.E., Vázquez de Aldana, B.R., Garcia Criado, B., García Ciudad, A., 1998. Variations in nutritional quality and biomass production of semiarid grasslands. J. Range Manage. 51, 570576. 
Plieninger, T., Hartel, T., Martín-López, B., Beaufoy, G., Bergmeier, E., Kirby, K., Montero, M.J., Moreno, G., Oteros-Rozas, E, Van Uytvanck, J., 2015. Wood-pastures of Europe: Geographic coverage, social-ecological values, conservation management, and policy implications. Biol. Conserv. 190, 70-79.

Puerto Martín, A., García Rodríguez, J.A., García Rodríguez, A., 1987. El sistema de ladera como elemento esclarecedor de algunos efectos del arbolado sobre el pasto. Centro de Edafología y Biología Aplicada del CSIC 12, 297-312.

Rhoades, C.C., 1997. Single-tree influences on soil properties in agroforestry: lessons from natural forest and savanna ecosystems. Agrofor. Syst. 35, 71-94.

Rivest, D., Paquette, A., Moreno, G., Messier, C., 2013. A meta-analysis reveals mostly neutral influence of scattered trees on pasture yield along with some contrasted effects depending on functional groups and rainfall conditions. Agric. Ecosyst. Environ. 165, 74-79.

Rodríguez-Estévez, V., García, A., Gómez-Castro, A.G., 2009. Intrinsic factors of acorns that influence the efficiency of their consumption by Iberian pigs. Livestock Science 122(2), 281-285.

Rodríguez-Estévez, V., García, A., Perea, J., Mata C., Gómez, A.G., 2007. Acorn production at the dehesa: influential factors. Arch. Zootec. 56 (R), 25-43.

San Miguel, A., 1994. La Dehesa Española. Origen, tipología, características y gestión. Fundación Conde del Valle de Salazar. Escuela Técnica Superior de Ingenieros de Montes. Madrid.

Silva-Pando, F.J., González-Hernández, M.P., Rozados-Lorenzo, M.J., 2002. Pasture production in a silvopastoral system in relation with microclimate variables in the Atlantic coast of Spain. Agrofor. Syst. 56, 203-211.

Tian, S., Cacho, J.F., Youssef, M.A., Chescheir, G.M., Fischer, M., Nettles, J.E., King, J.S., 2017. Switchgrass growth and pine-switchgrass interactions in established intercropping systems. Global Change Biology Bioenergy 9 (5), 845-857.

Tian, S., Cacho, J.F., Youssef, M.A., Chescheir, G.M., Nettles, J.E., 2015. Switchgrass growth and morphological changes under established pine-grass agroforestry systems in the lower coastal plain of North Carolina, United States. Biomass and Bioenergy 83, 233-244.

Van der Werf, W., Keesman, K., Burgess, P., Graves, A., Pilbeam, D., Incoll, L.D., Metselaar, K., Mayus, M., Stappers, R., van Keulen, H., Palma, J. and Dupraz, C., 2007. Yield-SAFE: A parameter-sparse, process-based dynamic model for predicting resource capture, growth, and production in agroforestry systems. Ecol. Eng. 29 (4), 419-433. 